\title{
Heterotopic brain tissue in the orbit: case report
}

\author{
JAMES E ELDER, ${ }^{1}$ C W CHOW,$^{2}$ AND ANTHONY D HOLMES 3 \\ From the 'Department of Ophthalmology, the ${ }^{2}$ Department of Anatomical Pathology, and the \\ ${ }^{3}$ Cranio-facial Surgery Unit, Royal Children's Hospital, Melbourne, Australia
}

SUMMARY A case of heterotopic brain tissue within the orbit is reported. Previously reported cases of this condition are reviewed, with particular reference to the pathogenesis and visual outcome.

The findings of heterotopic brain tissue wthin the orbit is extremely rare. A report of such a case follows.

\section{Case report}

A 2-year-old girl presented with a history of a slowly expanding mass in the region of the right medial canthus. The patient was born by a normal vaginal delivery after an uncomplicated pregnancy. Her parents noticed a small swelling in this region at birth. She has been otherwise well and has four normal older siblings.

Examination revealed a palpable swelling at the right medial canthus with shortening of the right palpebral aperture (right $20 \mathrm{~mm}$ and left $23 \mathrm{~mm}$ ). The right medial canthus was displaced laterally and inferiorly (Fig. 1). There was no proptosis. Fixation was central and steady with each eye, and the eyes were orthotropic to cover testing. Eye movements

Correspondence to Dr James Elder, Department of Ophthalmology, Royal Children's Hospital, Flemington Road, Parkville, Victoria 3052, Australia.

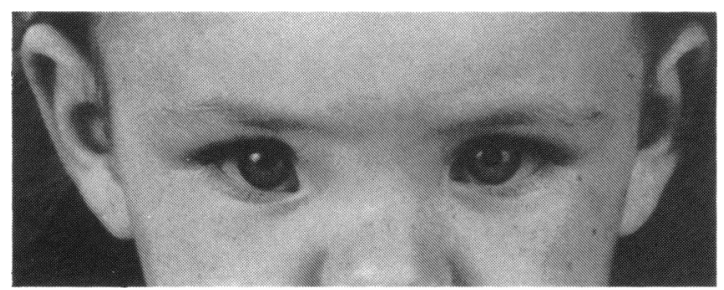

Fig. 1 Preoperative appearance showing swelling displacing medial canthus laterally and inferiorly. were full. She was emmetropic in both eyes and both fundi were normal.

CT scan showed a plaque-like mass involving the anteromedial portion of the right orbit (Fig. 2), displacing the medial wall towards the midline. No communication with the brain or cranial cavity was demonstrated. The clinical diagnosis at this stage was of an orbital dermoid.

At $2 \frac{1}{2}$ years of age the patient underwent a right orbitotomy via a craniofacial approach (coronal incision from right to left preauricular regions with mobilisation the anterior flap so as to expose the orbits from above). The periorbita were slightly thickened but stripped easily from the roof and medial wall of the orbit. The mass was entirely located within the periorbita. No bony defects were found in the roof or medial wall of the orbit. On opening the periorbita a reddish, friable, poorly encapsulated mass was found. It extended round both the superior oblique and the medial rectus and posteriorly beyond the equator of the globe. A macroscopically complete excision of the tumour mass was undertaken.

Histological examination showed masses of mature neuroglia with moderate numbers of normal looking neurons (Fig. 3). Extensive spotty calcification was seen, often round blood vessels. There was no surface differentiation to ependyma or choroid plexus, and non-neural elements were not found.

Postoperatively there was considerable periorbital oedema, which settled over one week. Visual function and ocular motility were both normal. Three months postoperatively the patient remained well and there was no evidence of recurrence of the mass. 


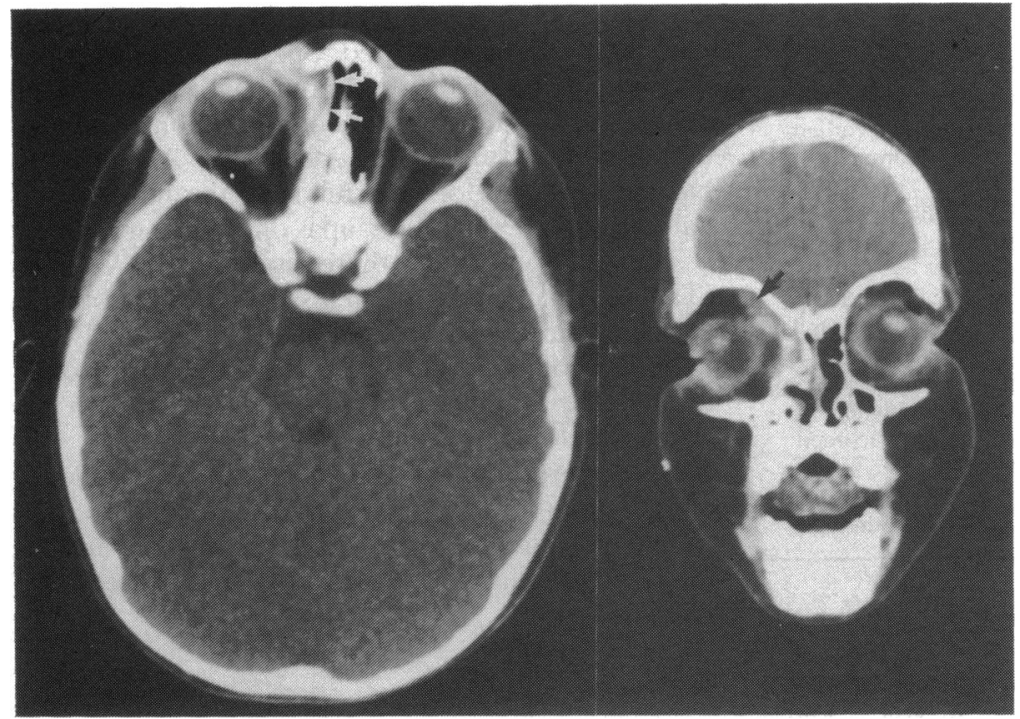

Fig. 2 Left: Horizontal CT scan demonstrating soft tissue mass in anteriomedial aspect of right orbit. Medial wall of orbit is displaced towards the midline but is intact (arrows). Right: Coronal CT scan showing mass (arrow) in the superomedial orbit with intact orbital roof and medial wall.

\section{Discussion}

Heterotopic brain in the orbit is very rare. Only four definite $^{1-4}$ and two possible cases $^{56}$ have been reported. (Two cases of limbal dermoids containing heterotopic brain have also been described. ${ }^{78}$ ) Encephaloceles and meningoencephaloceles with a demonstable connection with the brain or meninges are more commonly recognised within the orbit.

Extracranial heterotopic brain tissue has been described in a number of other sites in the head and neck, most commonly in the nasal region. These are generally known as nasal gliomas, and over 100 cases have been reported." Less frequently reported sites are naso- and oropharynx,,$^{10-15}$ palate, ${ }^{16}$ tongue, ${ }^{17}$ scalp, ${ }^{18}{ }^{14}$ and neck. ${ }^{21}$

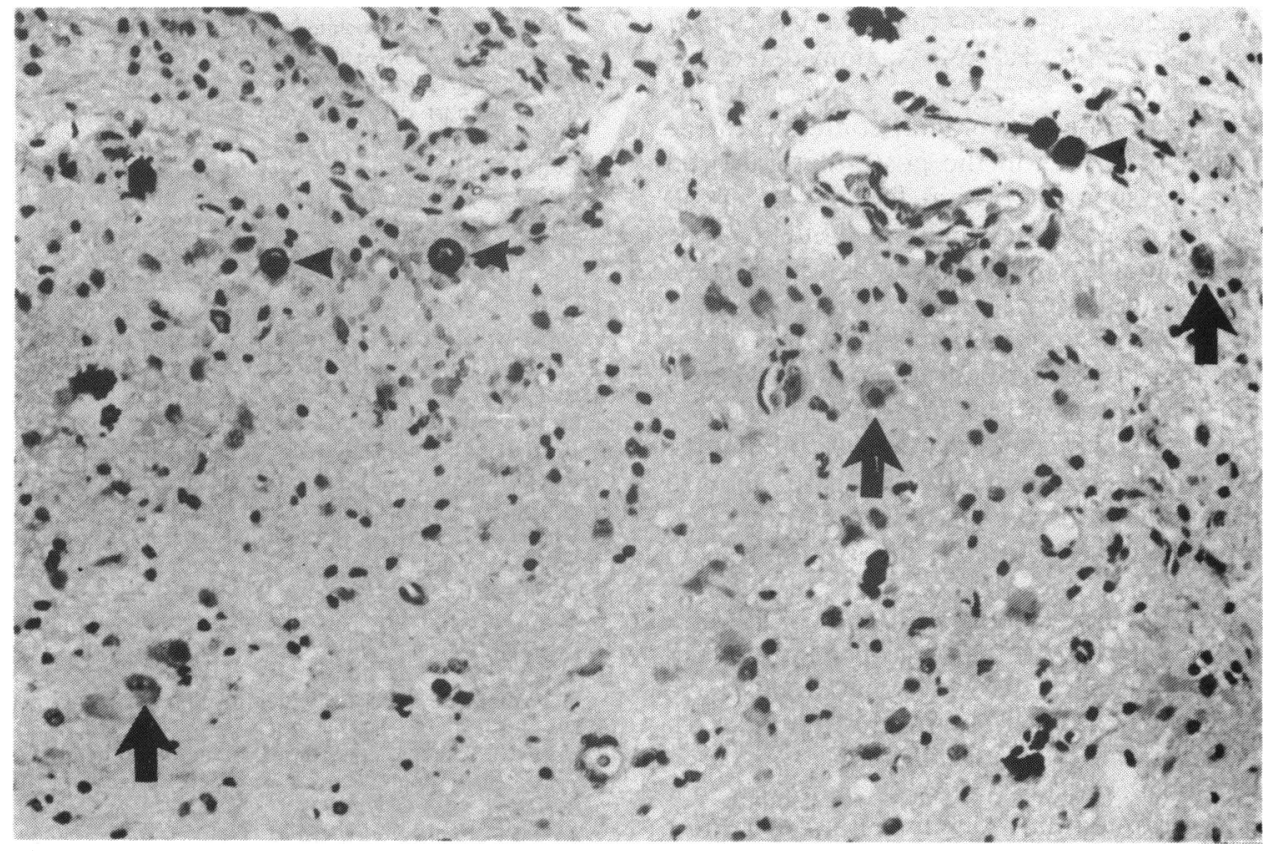

Fig. 3 Mature neuroglia with neurons (arrows) and focal calcification (arrowheads). ( $H$ and E, $\times 200)$. 
Table 1 Review of reported cases with visual outcome.

\begin{tabular}{|c|c|c|c|c|}
\hline No & Author & Year & Orbital lesion & Vision \\
\hline 1 & Acers` & 1965 & Encephalocele & Not recorded \\
\hline 2 & $\begin{array}{c}\text { Rodrigues and } \\
\text { Shannon" }\end{array}$ & 1977 & $\begin{array}{l}\text { Meningo- } \\
\text { encephalocele }\end{array}$ & 'Normal' \\
\hline 3 & Vaquero et al.' & 1980 & $\begin{array}{l}\text { Intraorbital } \\
\text { and intracranial } \\
\text { glial hamartoma }\end{array}$ & $\begin{array}{l}6 / 60, \text { optic } \\
\text { atrophy }\end{array}$ \\
\hline 4 & Call and Baylis & 1980 & $\begin{array}{l}\text { Cerebellar } \\
\text { heterotopia }\end{array}$ & $\begin{array}{l}\text { 'Decreased' } \\
\text { afferent pupil } \\
\text { defect }\end{array}$ \\
\hline 5 & Newman et al.' & 1986 & $\begin{array}{l}\text { Heterotopic } \\
\text { brain }\end{array}$ & $\begin{array}{l}\text { 1/60, dense } \\
\text { amblyopia }\end{array}$ \\
\hline 6 & Wilkins et al. ${ }^{+}$ & 1987 & $\begin{array}{l}\text { Heterotopic } \\
\text { brain }\end{array}$ & Not recorded \\
\hline 7 & Elder et al. & 1988 & $\begin{array}{l}\text { Heterotopic } \\
\text { brain }\end{array}$ & $\begin{array}{l}\text { Normal fixation } \\
\text { pattern }\end{array}$ \\
\hline
\end{tabular}

The genesis of heterotopic brain is not clear, and a number of theories have been suggested. These include (1) herniation of the intracranial contents through a skull defect which subsequently closes, leaving no direct connection between the heterotopic focus and the brain; (2) early separation of neuroectodermal rests; (3) teratomatous malformation with proliferation of a single cell line; (4) true astrocytomas; and (5) migration of glial cells along the olfactory nerves during embryogenesis. ${ }^{311021}$ Only the first theory is widely accepted.

In this case there was no evidence of a bony defect nor of any connection with the cranial cavity. In four of the previously reported cases ${ }^{1346}$ a bony defect was found, though intact dura mater separated the heterotopic brain from the cranial contents. In the fifth case ${ }^{2}$ the mass was in the posterolateral orbit adjacent to the superior orbital fissure, and postoperatively there was fluid leakage thought to be cerebrospinal fluid. It is not clear whether this leakage was due to the surgery or represented a pre-existing connection with the subarachnoid space. The report of the remaining case ${ }^{5}$ describes radiological evidence of adjacent bony erosion but does not provide any operative findings on the integrity of the orbital walls.

Histological examination in this case showed mature glia and neurons, with extensive calcification, which was probably secondary and is common in malformations.

In a previous case report ${ }^{3}$ striated cells were intermixed with glial tissue. This has been interpreted as local invasiveness. However, striated cells have been found in heterotopic brain in sites remote from normal muscle and in glial cell cultures. ${ }^{22}$

These lesions are slow growing and have not shown malignant features. ${ }^{34}$ Further growth after incomplete resection has been described in two cases. ${ }^{34}$ In both of these cases the recurrent was in part cystic, and repeated operations have been required to remove the tumour mass. Histological examination after subsequent operations revealed tissue identical to original specimens. As yet there has been no sign of recurrence of the mass in our patient, though the follow-up is only three months.

The visual outcome in these cases has been variable (Table 1). in one case visual loss was presumably due to strabismic amblyopia ${ }^{3}$ and in another possibly due to optic atrophy.' In our case the patient is too young for reliable estimation of visual acuity, though her visual development appears to be normal.

Given the potential for visual loss and the tendency of the tumour to recur after attempted resection, frequent ophthalmological review and early surgical intervention in the case of recurrence are recommended.

\section{References}

1 Vaquero J, Cabezudo JM, Leunda G, Carrillo R, Bravo G. Intraorbital and intracranial glial hamartoma: case report. J Neurosurg 1980; 53: 117-20.

2 Call NB, Baylis HI. Cerebellar heterotopia in the orbit. Arch Ophthalmol 1980: 98: 717-9.

3 Newman NJ, Miller NR, Green WR. Ectopic brain in the orbit. Ophthalmology 1986; 93: 268-72.

4 Wilkins RB, Hofmann RJ, Font RL. Heterotopic brain tissue in the orbit. Arch Ophthalmol 1987: 105: 390-2.

5 Acers TE. Encephalocele. Arch Ophthalmol 1965; 73: 84-5.

6 Rodrigues M, Shannon G. Orbital meningoencephalocele in a healthy adult. Can J Ophthalmol 1977: 12: 63-5.

7 Hutchison DS, Green WR, Iliff CE. Ectopic brain tissue in a limbal dermoid associated with a scleral staphyloma. Am J Ophthalmol 1973; 76: 984-6.

8 Emamy H, Ahmadian H. Limbal dermoid with ectopic brain tissue. Report of a case and review of the literature. Arch Ophthalmol 1977: 95: 2201-2.

9 Batsakis JG. Tumors of the head and neck. Clinical and pathological considerations. 2nd ed. Baltimore: Williams and Wilkins, 1979: 334-7.

10 Karma P, Rasanen O, Karja J. Nasal gliomas. A review and report of two cases. Laryngoscope 1977; 76: 1169-79.

11 Ruff T, Diaz JA. Heterotopic brain in the nasopharynx. Otolaryngol Head Neck Surg 1986; 94: 254-6.

12 Seibert RW, Seibert JJ, Jimenez JF, Angtuaco EJ. Nasopharyngeal brain heterotopia - a cause of upper respiratory airway obstruction in infancy. Laryngoscope 1984; 94: 818-9.

13 Bratton AB, Robinson SHG. Gliomata of nose and oral cavity. A report of two cases. J Pathol Bacteriol 1946; 58: 643-8.

14 Alexander TA. Nasl glioma. J Pediatr Surg 1978; 13: 522-4.

15 Cohen $\mathrm{AH}, \mathrm{Abt} \mathrm{AB}$. An unusual cause of neonatal respiratory obstruction: heterotopic pharyngeal brain tissue. J Pediatr 1970; 76: $119-22$.

16 Ibekwe AO, Ikerionwu SE. Heterotopic brain tissue in the palate. J Laryngol Otol 1982: 96: 1155-8.

17 Ofodile FA, Aghadinuo PU, Oyemade O, Adebonojo T. Heterotopic brain tissue in the tongue. Plast Reconstr Surg 1982: 69: $120-4$.

18 Orkin M, Fisher I. Heterotopic brain tissue (heterotopic neural crest): case report with review of related anomalies. Arch Dermatol 1966; 94: 699-708.

19 Zook EG, Nickey WM, Pribaz JJ. Heterotopic brain tissue in the scalp. Plast Reconstr Surg 1984; 73: 660-3. 
20 Robbins SH, Tomaszewski M, Garcia VF, Eggli KD, d'Avis JC. Heterotopic brain presenting as acystic neck mass with mandibular deformity. Pediatr Pathol 1985; 4: 341-9.

21 Whitaker SR, Sprinkle PM, Chou SM. Nasal glioma. Arch Otolaryngol 1981: 107: 550-4.
22 Johnson ES, Ludkin SK. Rhabdoneuroglial heterotopias in the pontine leptomeninges in trisomy 13. Arch Pathol Lab Med 1984: 108: $906-8$.

Accepted for publication 24 April 1989 